\title{
Ultrastructure of Vernonia galamensis (Cass.) Less Glandular Trichomes
}

\author{
Francoise Favi, Edwina Westbrook, Tadesse Mebrahru and Mark Kraemer
}

Agricultural Research Station, Virginia State University, Petersburg, VA 23806

The genus Vernonia contains more than 500 species distributed in Africa and South America. Vernonia galamensis (Cass.) Less, is divided into several subspecies and varieties [1]. We are currently studying $V$. galamensis ssp. galamensis var. ethiopica, an herbaceous plant from Eritrea in northeast Africa and a potential new oilseed crop [2]. The oil is rich in epoxy fatty acids that are characterized by unusually low viscosity. These oils can be used in paints to reduce volatile organic emissions, and in plasticizers and additives for flexible polyvinyl chloride resins. The leaves of $V$. galamensis contain biologically active compounds and are used in traditional medicine for stomach aches [3] and parasitic disease [4]. Constituents from dried leaves have been isolated but nothing has been published on trichome structure. Transmission and scanning electron microscopes were used in this study. Peltate glandular trichomes were only present on the lower side of leaves (Figs. 1,2). These trichomes were composed of (from bottom to top) an elongated pair of support cells, several pairs of secretory cells with vacuoles, and a head filled with a product (Fig. 3). What appear to be developmental stages of the glandular trichomes have fewer secretory cells and lack a head (Figs. 3b, 3c) [5].

\section{References}

[1] C. Jeffrey, 1988. The Vernonieae in East Tropical Africa. Notes on Compositae: V. Kew Bulletin, 43: 195-276.

[2] D.A. Dierig et al., 1966. Lesquerella and Vernonia: Oilseeds for Arid Lands. In Progress in New Crops. Jules Janick (ed.) Purdue University. p. 347-362.

[3] S.C. Chhabra et al., 1989. Plants used in traditional medicine in Eastern Tanzania. II. Angiosperms (Capparidaceae to Ebenaceae). Journal of Ethnopharmacology. 25: 339-359.

[4] M. Gasquet et al., 1985. Action amoebicide et anthelmintique du vermolide et de l'hydroxyvernolide isolés des feuilles de Vernonia colorata (Willd.) Drake. European Journal of Medicinal Chemistry-Chimie Thérapeutique, 20: 111-115.

[5] F. Favi and S. Eversman. 2002. Glandular trichomes of the mountain big sagebrush Artemisia tridentata vaseyana (Rydb.) Beetle: ultrastructure and terpenoid composition. Annual Meeting of the Entomological Society of America, Nov. 17-20, Fort Lauderdale, Fla. 


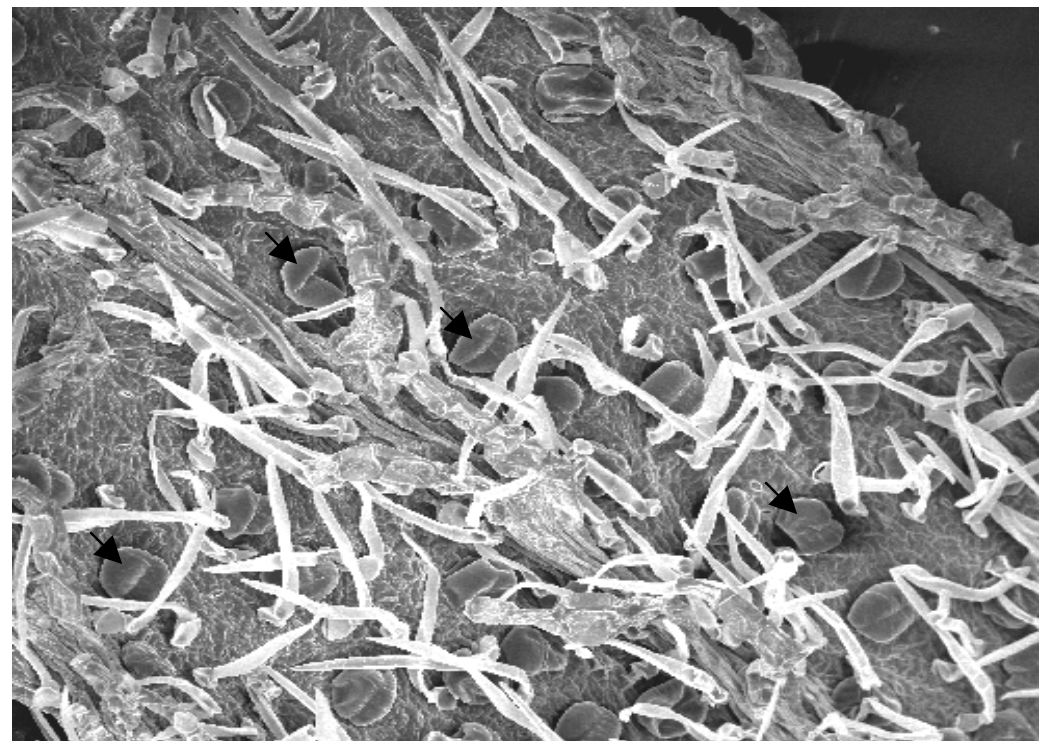

Figure 1: SEM of lower side of Vernonia leaf. Numerous glandular trichomes (arrows) appear among apparent non-glandular trichomes. Original magnification X50.
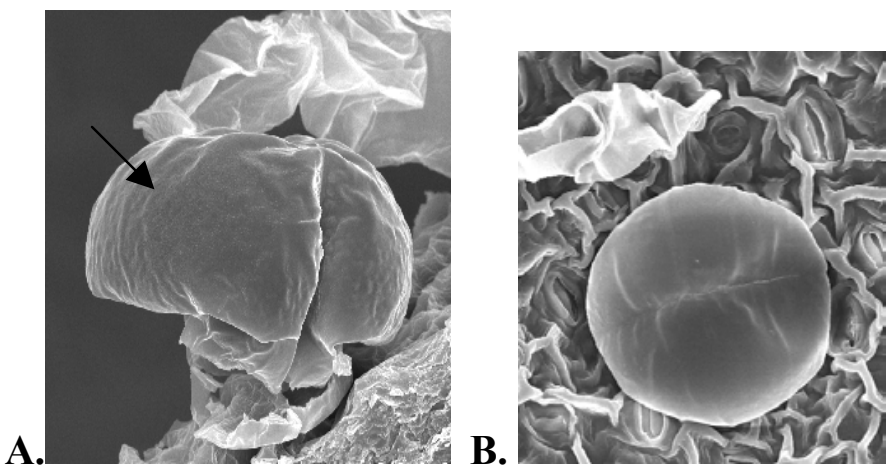

Figure 2: SEM of trichomes from side view showing head (arrow) (A) and from top view (B). Original magnification X900.
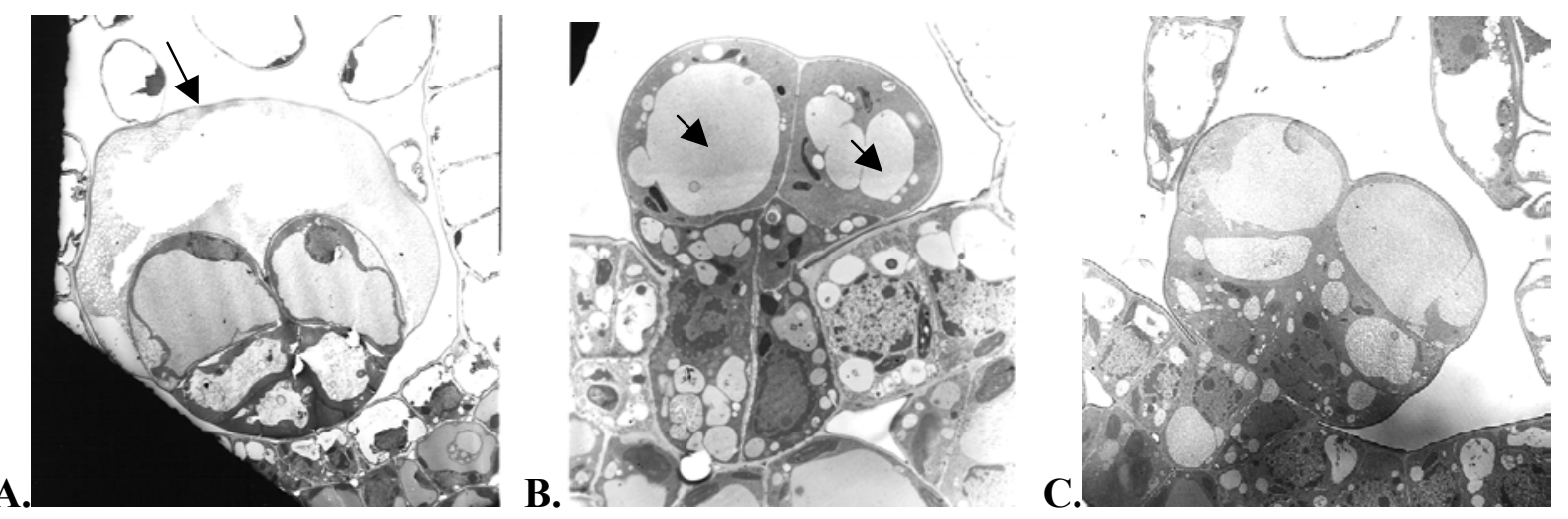

Figure 3: TEM of glandular trichomes. A: Trichome with secretion filled head (arrow). Original magnification X1500. B: Trichome with two cells above epidermal layer anchored by two support cells. Notice the large vacuoles (arrows). Original magnification X3000. C: Apparent developmental stage of trichome. Original magnification X1500. 